\title{
Ecomorphological Traits Determine Assemblage Pattern of Small Freshwater Fish in Smaller Lentic Aquatic Bodies
}

\author{
S. Roy ${ }^{1,2}$, S. I. Maiti ${ }^{3}$, S. K. Saikia ${ }^{1 *}$, S. Ray ${ }^{2}$ \\ ${ }^{1}$ Aquatic Ecology and Fish Biology Laboratory, Department of Zoology, Visva-Bharati University, \\ Santiniketan, West Bengal - 731235, India \\ ${ }^{2}$ Systems Ecology and Ecological Modelling Laboratory, Department of Zoology, Visva-Bharati \\ University, Santiniketan, West Bengal - 731235, India \\ ${ }^{3}$ Department of Statistics, Visva-Bharati University, Santiniketan, West Bengal - 731235, India
}

Received 17 March 2020, accepted in final revised form 22 May 2020

\begin{abstract}
The present study investigated ecomorphological patterns of fish assemblage from freshwater ponds on two functional categories, i.e., foraging behavior and habitat preference. Nine ecomorphological indices were derived from eight morphometric variables and examined on 566 adult individuals belonging to 9 species, 7 families and 4 orders. Samples were collected during April 2016 to September 2017 from freshwater ponds in Birbhum, West Bengal. Mantel test was performed to investigate correlation between morphological, taxonomic, trophic and habitat guild matrices. The partial Mantel test was done to investigate the direct correlation between trophic and habitat guilds with morphology discounting the effect of taxonomic relatedness on species assemblage. The interspecific ecomorphological diversification pattern was analysed by HCPC method. At least three ecomorphological assemblages among these fish species with two significant principal axes of variations were observed. Ecomorphological attributes associated with mouth aspect ratio, compression index and relative body height were on PC1 axis, and relative length and height of head, relative area of eye were on PC 2 axis. Mantel and partial Mantel test showed significant correlation between morphology and trophic guild structure. Outcomes show that morphology is a good predictor of trophic structure of fish assemblage in studying convergent assemblage pattern irrespective of taxonomy.
\end{abstract}

Keywords: Freshwater fish; Trophic Guild; Habitat guild; Mantel Test; $k$-Means Clustering;

(c) 2020 JSR Publications. ISSN: 2070-0237 (Print); 2070-0245 (Online). All rights reserved. doi: http://dx.doi.org/10.3329/jsr.v12i4.45998

J. Sci. Res. 12 (4), 713-727 (2020)

\section{Introduction}

Ecomorphology reveals how natural selection influences community assembly in an environment through changes in the morphology of species [1]. It has been well demonstrated that morphological traits reflect adaptation to a particular environment in geographically and taxonomically disparate assemblages of fish species [2,3]. In fish, ecomorphological studies primarily focussed on the relationship between body

\footnotetext{
*Corresponding author: surjyasurjya@gmail.com
} 
morphology and pattern of use of resources that contribute to understanding the realised niche of the fish species in a habitat [4,5]. In freshwater riverine fish, studies on ecomorphological traits and associated functions of fish have provided strong evidence of community assemblage based on prey capture, diet, foraging methods, mode of locomotion [6-8]. In streams, Pease et al. [9] reported that the environmental variables are related to the functional traits resulting stream fish assemblages where more streamlined bodied fish prefer a habitat at high elevation lacking pool habits, whereas fish with longer fins, longer gill rakers, deeper bodies and large eyes prefers lower elevation with more pool habitat, deeper channel and more rainfall. In micro-environments, like tide pools, it has been found that pelagic fish species were grouped with benthic ones for resource exploration [10]. Such findings affirm how morphological traits of fish species contribute to assembly pattern in order to use different resources in an environment.

In general, it is assumed that small-sized fish are strongly correlated to microhabitat structure [11]. Therefore, in case of small freshwater fish species (SFSs) (size $<25 \mathrm{~cm}$ ) [12], evidence for adaptational adjustments could be interesting as their dwelling zones are limited and overlapped, and even, sometimes they spend their whole life in a tiny microhabitat stand. On the other hand, these fish species are often excluded from ecomophological studies since they occupy a lower trophic hierarchy compared to largesized fishes. At the same time, these fishes are reported to be under serious threat $[13,14]$ due to habitat loss, fragmentation $[15,16]$ and predation [17] making them vulnerable to extreme changes in the environment [18]. Unlike those river and stream fishes cited above, there is a wider knowledge gap on ecomorphological based form-function interaction leading to morphological convergence in SFSs thriving in smaller lentic aquatic bodies like ponds, ditches, canals.

The present study, therefore, aimed to investigate the correlations between species morphological variables to trophic and habitat guilds and their possible interspecific ecomorphological patterns of assemblage. The study describes ecomorphological assemblage of SFSs from smaller lentic freshwater bodies based on a range of morphological traits. It evaluates fish assemblages concerning habitat use and feeding guilds after eliminating taxonomic effect.

\section{Methods}

\subsection{Study area and sampling}

Freshwater ponds $(\mathrm{n}=8)$ around Birbhum $\left(23.8402^{\circ} \mathrm{N}, 87.6186^{\circ} \mathrm{E}\right)$, West Bengal (India) were selected for collection of fish species (Fig. 1). These ponds were natural and perennial, with an average area about 400 square feet and an average depth about $5 \mathrm{~m}$ and not connected to any river or stream. Random sampling was done for small fish species and was collected from April 2016 to September 2017. Only those small fishes with $70 \%$ or more catch per effort were considered for analysis. Fishes were caught during early hours of the day using a cast net, and immediately transferred to an icebox after mildly 
treating with MS222 and then taken to the laboratory for morphometric analysis. Fish were identified according to Talwar and Jhingran [19].

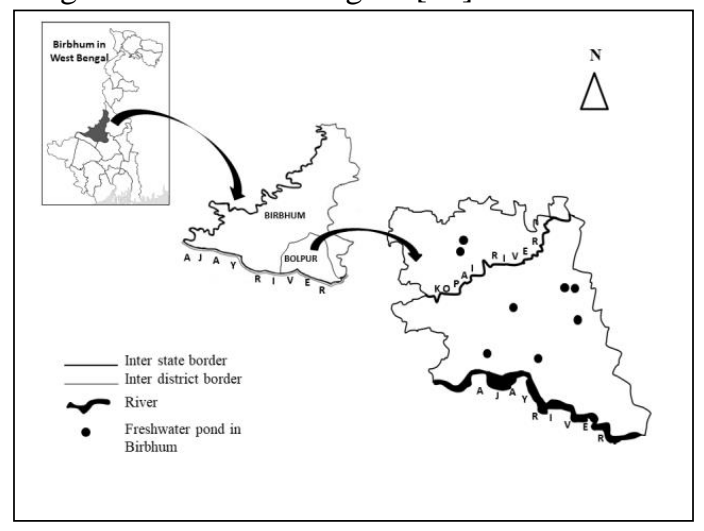

Fig. 1. Site map of Birbhum (West Bengal) where sampling of fish was performed.

A total of 566 adult individuals from 9 freshwater fish species $(7$ families and 4 orders) were selected for the variability of their feeding behaviour and habitat preference namely Puntius sophore (Hamilton 1822), Amblypharyngodon mola (Hamilton 1822), Esomus danrica (Hamilton 1822), Lepidocephalichthys guntea (Hamilton 1822), Chanda nama (Hamilton 1822), Parambassis lala (Hamilton 1822), Trichogaster fasciata (Bloch and Schneider 1801), Glossogobius giuris (Hamilton 1822) and Anabas testudineus (Bloch 1792). The species were small in size, i.e., the total length of fish does not exceed $25 \mathrm{~cm}$ throughout their lifetime. The representative figures of all these species are shown in Fig. 2 and IUCN status (2018) [20] of these 9 small fish species of sample size; total lengths are shown in Table 1. The mean total length of these fish species ranges from 2.8 $8.73 \mathrm{~cm}$.

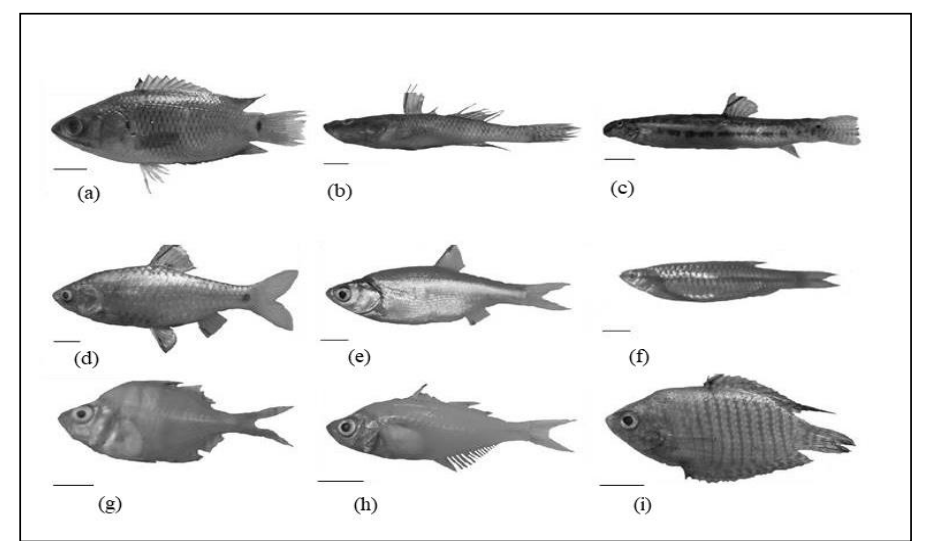

Fig. 2. Selected freshwater fish species- a. Anabas testudineus, b. Glossogobius giuris, c. Lepidocephalichthys guntea, d. Puntius sophore, e. Amblypharyngodon mola, f. Esomus danrica, g. Parambassis lala, h. Chanda nama and i. Trichogaster fasciata. Inkscape and Adobe Photoshop were used for fish outline drawings, (-) represented $1 \mathrm{~cm}$ for each fish species. 
Table 1. The sample size, mean total length $(\mathrm{cm})$, maximum total length $(\mathrm{cm})$ and IUCN status of 9 selected fish species.

\begin{tabular}{|c|c|c|c|c|c|c|}
\hline Order & Family & Species & $\begin{array}{l}\text { Sample } \\
\text { size } \\
\text { (n) }\end{array}$ & $\begin{array}{l}\text { Mean } \\
\text { total } \\
\text { length } \\
(\mathrm{cm}) \\
\end{array}$ & $\begin{array}{l}\text { Maxm. } \\
\text { total } \\
\text { length } \\
(\mathrm{cm})\end{array}$ & $\begin{array}{l}\text { IUCN } \\
\text { status }\end{array}$ \\
\hline \multirow[t]{4}{*}{ Cypriniformes } & \multirow[t]{3}{*}{ Cyprinidae } & $\begin{array}{l}\text { Puntius sophore } \\
\text { (Hamilton, 1822) }\end{array}$ & 155 & 7.5 & 10.61 & $\begin{array}{l}\text { Least } \\
\text { Concern }\end{array}$ \\
\hline & & $\begin{array}{l}\text { Amblypharyngodon mola } \\
\text { (Hamilton, 1822) }\end{array}$ & 68 & 5.66 & 8.9 & $\begin{array}{l}\text { Least } \\
\text { Concern }\end{array}$ \\
\hline & & $\begin{array}{l}\text { Esomus danrica } \\
\text { (Hamilton, 1822) }\end{array}$ & 30 & 5.42 & 6.7 & $\begin{array}{l}\text { Least } \\
\text { Concern }\end{array}$ \\
\hline & Cobitidae & $\begin{array}{l}\text { Lepidocephalichthys } \\
\text { guntea } \\
\text { (Hamilton, 1822) }\end{array}$ & 42 & 5.96 & 8.18 & $\begin{array}{l}\text { Least } \\
\text { Concern }\end{array}$ \\
\hline \multirow[t]{5}{*}{ Perciformes } & \multirow[t]{2}{*}{ Ambassidae } & $\begin{array}{l}\text { Chanda nama } \\
\text { (Hamilton, 1822) }\end{array}$ & 62 & 4.70 & 7.9 & $\begin{array}{l}\text { Least } \\
\text { Concern }\end{array}$ \\
\hline & & $\begin{array}{l}\text { Parambassis lala } \\
\text { (Hamilton, 1822) }\end{array}$ & 37 & 2.80 & 3.2 & $\begin{array}{l}\text { Least } \\
\text { Concern }\end{array}$ \\
\hline & Osphronemidae & $\begin{array}{l}\text { Trichogaster fasciata } \\
\text { (Bloch \& Schneider, 1801; }\end{array}$ & 33 & 4.24 & 7.6 & $\begin{array}{l}\text { Least } \\
\text { Concern }\end{array}$ \\
\hline & Gobiidae & $\begin{array}{l}\text { Glossogobius giuris } \\
\text { (Hamilton, 1822) }\end{array}$ & 72 & 8.73 & 15.06 & $\begin{array}{l}\text { Least } \\
\text { Concern }\end{array}$ \\
\hline & Anabantidae & $\begin{array}{l}\text { Anabas testudineus } \\
\text { (Bloch, 1792) }\end{array}$ & 67 & 6.81 & 14.3 & $\begin{array}{l}\text { Data } \\
\text { Deficient }\end{array}$ \\
\hline
\end{tabular}

\subsection{Ecomorphological indices}

Nine ecomorphological indices (Table 2) were calculated, which were derived from eight morphometric measurements (Fig. 3). These indices are widely applied to interpret the functions like foraging, position and locomotion of fish. Measurements were taken from the left side of the body of each specimen. All measures were recorded using $150 \mathrm{~mm}$ digital callipers with a precision of $0.1 \mathrm{~mm}$.

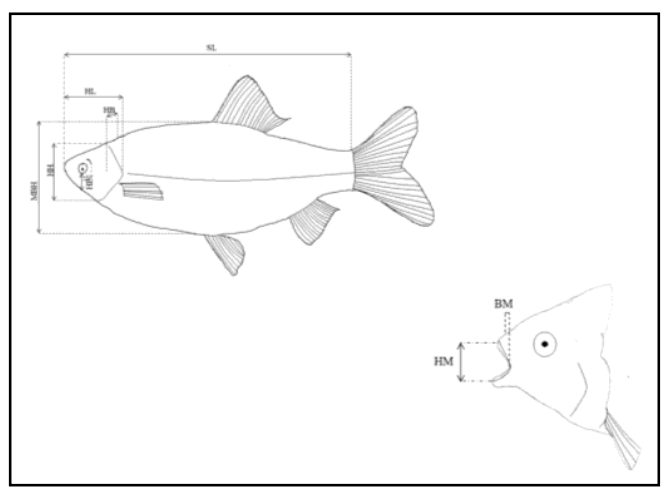

Fig. 3. Generalised schematic diagram of a fish species with linear morphometric measurements used for calculating ecomorphological index: Standard Length (SL), Head Length (HL), Head Height (HH), Breadth of the Mouth (BM), Height of Mouth (HM), Head Breadth (HB), Height of Eye (HE) and Maximum Body Height (MBH). Inkscape and Adobe Photoshop were used for fish outline drawings. 
Table 2. Ecomorphological indices related to foraging, position, locomotion derived from morphometric data and their ecological implications. Standard Length (SL), Head Length (HL), Head Height (HH), Breadth of the Mouth (BM), Height of Mouth (HM), Head Breadth (HB), Height of Eye (HE) and Maximum Body Height (MBH).

\begin{tabular}{|c|c|c|}
\hline $\begin{array}{l}\text { Ecomorphological } \\
\text { indices }\end{array}$ & Formula & Implications \\
\hline $\begin{array}{l}\text { Relative length of head } \\
\text { (RLH) }\end{array}$ & HL/SL & \multirow{4}{*}{$\begin{array}{l}\text { High values are associated with ability to capture } \\
\text { larger sized prey and are expected to be piscivorous } \\
\text { [21-23]. }\end{array}$} \\
\hline $\begin{array}{l}\text { Relative width of mouth } \\
\text { (RWM) }\end{array}$ & $\mathrm{BM} / \mathrm{SL}$ & \\
\hline $\begin{array}{l}\text { Relative height of } \\
\text { mouth (RHM) }\end{array}$ & $\mathrm{HM} / \mathrm{SL}$ & \\
\hline $\begin{array}{l}\text { Relative height of head } \\
\text { (RHH) }\end{array}$ & $\mathrm{HH} / \mathrm{MBH}$ & \\
\hline $\begin{array}{l}\text { Relative area of eye } \\
\text { (RAE) }\end{array}$ & $\pi^{*}(\mathrm{HE} / 2)^{2} / \mathrm{SL}^{2}$ & $\begin{array}{l}\text { High values are associated with increased use of vision } \\
\text { during predatory behavior [21]. }\end{array}$ \\
\hline $\begin{array}{lll}\begin{array}{l}\text { Mouth } \\
\text { (MAR) }\end{array} & \text { aspect } & \text { ratio } \\
\end{array}$ & $\mathrm{HM} / \mathrm{BM}$ & $\begin{array}{l}\text { High values are associated with narrower mouth and } \\
\text { large aperture [24]. }\end{array}$ \\
\hline Compression index (CI) & $\mathrm{MBH} / \mathrm{HB}$ & $\begin{array}{l}\text { High values are associated with species inhabiting } \\
\text { lentic environment and a laterally compressed fish } \\
\text { [25]. }\end{array}$ \\
\hline $\begin{array}{l}\text { Relative eyes position } \\
\text { (REP) }\end{array}$ & $\mathrm{HE} / \mathrm{MBH}$ & $\begin{array}{l}\text { Benthic fishes have more dorsally located eyes than } \\
\text { nektonic fishes [26]. }\end{array}$ \\
\hline Relative height (RH) & $\mathrm{MBH} / \mathrm{SL}$ & $\begin{array}{l}\text { High values for species with greater potential for } \\
\text { maneuverability, low values with more elongated fish } \\
{[26] \text {. }}\end{array}$ \\
\hline
\end{tabular}

\subsection{Diet composition and preferred habitat}

All 9 fish species were classified as omnivore, herbivore, insectivore and other carnivores based on most dominant gut contents (maximum proportion) available from published data. The habitat types were also classified as benthic, water column and subsurface based on published data (Table 3).

Table 3. Trophic and habitat guilds of selected fish species.

\begin{tabular}{lll}
\hline Species name & Trophic guild & Habitat guild \\
\hline Puntius sophore & Omnivore [27] & Water column [33,40,41] \\
Amblypharyngodon mola & Herbivore [28,29] & Subsurface [33] \\
Esomus danrica & Omnivore [30] & Subsurface [41] \\
Lepidocephalichthys guntea & Omnivore [31] & Benthic [41] \\
Chanda nama & Insectivore [32-34] & Water column [34,41] \\
Parambassis lala & Insectivore & Water column [33] \\
Trichogaster fasciata & Omnivore [33] & Water column [33] \\
Glossogobius giuris & Other Carnivore [35-38] & Benthic \\
Anabas testudineus & Other Carnivore [33,39] & Water column [33] \\
\hline
\end{tabular}




\subsection{Data analysis}

\subsubsection{Ecomorphological structure of fish assemblage}

The null hypothesis that morphological patterns of the fish assemblage are independent of taxonomic influence was evaluated using Mantel test. Mantel tests were applied for analysing foraging and habitat use related traits. The correlation between the taxonomic matrix with two morphological and two categorical (trophic and habitat use) matrices was tested through 10,000 permutations at $p$ value $<0.05$. Mantel test expression is given by the following formula [42]

$$
Z=\sum_{i=1}^{n} \sum_{j=1}^{n} X_{i j} Y_{i j} \text { for } i \neq j, n=\text { no of randomizations }
$$

in which, $\mathrm{X} i j$ and $\mathrm{Y} i j$ are the elements of the two different matrices that are being tested for association.

Depending on the taxonomic structure of the data, total or partial Mantel test was performed to investigate the role of trophic guild or habitat use in structuring ecomorphological assemblage after eliminating taxonomic signal.

For sample morphological matrix, mean Euclidian distances were calculated between ecomorphological indices of each pair of species using the following formula [43]

$D_{j k}=\left[\sum_{i=1}^{n}\left(x_{i j}-x_{i k}\right)^{2}\right]^{1 / 2}$

Where $n=$ number of ecomorphological indices, $x_{i j}$ and $x_{i k}$ are values of ecomorphological index $i$ for a pair of species $j$ and $k$.

For model matrix of trophic guild (i.e., omnivore, herbivore, insectivore and other carnivore), matrices were deduced from pairwise comparison of species attributing a value of ' 1 ' to the pair of species that belonged to the same trophic guild and value of ' 0 ' to the pair that did not share the same condition. A similar procedure was followed for spatial model matrix (i.e., benthic, water column and subsurface). Also for the model matrix of taxonomic distance, pairs of species that belong to the same genus have given a value of ' 1 ', '2' for same family, ' 3 ' for same order and ' 4 ' when belonging to a different order. Order Cyprinifomes is the basal clad of Otophysi and exhibits a greater taxonomic distance from other orders, i.e., here Perciformes, Gobiiformes and Anabantiformes that are clustered within Euteleostei. So, if a pair of species belongs to different order and Cypriniformes, they have given a value of ' 5 '. The Mantel test and partial Mantel test were carried out using the PAST (Paleontological Statistics, version 2.17) [44] software.

\subsubsection{Interspecific ecomorphological diversification pattern of fish assemblage}

The mean values of all indices were analysed to verify the presence of multicollinearity problem. Any kind of linear dependence among those indices mentioned above was swept out by calculating sample correlation coefficients and their corresponding $p$-value. The 
indices for which correlation coefficients were significant were dropped. The basic rule of thumb is: indices having correlation beyond 0.7 were eliminated [10].

To accomplish the objective, three combined standard multivariate data analysis methods in sequence were adopted (Hierarchical Clustering Principal Component, HCPC)-- 1) Principal component analysis (PCA), 2) Hierarchical clustering and 3) $k$ means clustering method. PCA, as a pre-processing step, can be viewed as a denoising method. The indices which score comparatively high on each axis were selected for the interpretation. Next, hierarchical clustering was performed to obtain a rough partitioning of species. Finally, in order to infer on the shape of species similarity cloud in a better way, the initial partitioning due to hierarchical clustering was improved by more mathematically sound $k$-means clustering strategy. Here, Ward's criterion was used as within-group criteria in choosing out the optimum number of clusters [45]. Statistical analyses were performed in FactoMineR and Factoextra packages from $\mathrm{R}$ studio version 1.1.456.

\section{Results and Discussion}

\subsection{Ecomorphological structure of fish assemblage}

The results of Mantel test revealed a significant correlation between taxonomic matrix and foraging related morphological distance matrix (one-tailed test, $p=0.0262$ ) as well as between taxonomic matrix and trophic guild matrix (one-tailed test, $p=0.0497$ ). Therefore, the morphological pattern of assemblage is dependent on trophic and taxonomic structure (Table 4). Considering this taxonomic signal into the dataset, the association between morphological matrix and trophic guild matrix was tested, and the result showed a significant and robust correlation between them (one-tailed test, $p=$ 0.0003). Such correlation between the trophic-morphological structures may be a product of taxonomic relationships. So, to eliminate the taxonomic influence from data, partial Mantel test was performed. Result indicated that foraging related morphological structure is directly correlated to trophic guild structure (one-tailed test, $p=0.0004$ ) (Table 4).

The results of Mantel test between taxonomic matrix and habitat use related morphological distance matrix did not show any correlation (one-tailed test, $p=0.221$ ), whereas taxonomic matrix and habitat guild matrix presented weak correlation (one-tailed test, $p=0.07$ ) (Table 4). Further, the test result between morphological matrix and habitat guild matrix did not reveal significant correlation (one-tailed test, $p=0.588$ ) (Table 4), which promotes that fish assemblage is partly structured by taxonomic relatedness. 
Table 4. Mantel test correlating ecomorphological distance matrix with the trophic guild, habitat guild and taxonomic distance matrices. Significant values $(<0.05)$ are marked in bold.

\begin{tabular}{|c|c|c|}
\hline Statistical test & $r$ value & $\begin{array}{l}P \text { value (one- } \\
\text { tailed test) }\end{array}$ \\
\hline \multicolumn{3}{|l|}{ Mantel test } \\
\hline $\begin{array}{l}\text { Taxonomic distance matrix } \times \text { Foraging related morphological } \\
\text { distance matrix }\end{array}$ & 0.3091 & 0.0262 \\
\hline $\begin{array}{l}\text { Taxonomic distance matrix } \times \text { Habitat use related morphological } \\
\text { distance matrix }\end{array}$ & 0.0609 & 0.221 \\
\hline Taxonomic distance matrix $\times$ Trophic guild matrix & 0.3029 & 0.0497 \\
\hline Taxonomic distance matrix $\times$ Habitat guild matrix & 0.2109 & 0.0704 \\
\hline $\begin{array}{l}\text { Trophic guild matrix } \times \text { Foraging related morphological distance } \\
\text { matrix }\end{array}$ & 0.6746 & 0.0003 \\
\hline $\begin{array}{l}\text { Habitat guild matrix } \times \text { Habitat use related morphological distance } \\
\text { matrix }\end{array}$ & -0.142 & 0.5886 \\
\hline \multicolumn{3}{|l|}{ Partial Mantel test } \\
\hline $\begin{array}{l}\text { residuals (Foraging related morphological distance matrix } \times \\
\text { Taxonomic distance matrix) } \times \text { residuals (Trophic guild matrix } \times \\
\text { Taxonomic distance matrix) }\end{array}$ & 0.641 & 0.0004 \\
\hline
\end{tabular}

\subsection{Interspecific ecomorphological pattern of fish assemblage}

The highly correlated variables were identified by Pearson correlation test and corresponding ecomorphological indices (relative width of mouth, RWM and relative height of mouth, RHM) were eliminated from subsequent analyses. It means that the rest of the 7 ecomorphological indices were only used for multivariate data analysis.

PCA performed on the correlation matrix computed from the original data. The first three Principal Components (PCs) explained almost $91 \%(41.7 \%+29.2 \%+20.2 \%)$ of total data variation. Here, PC3 was deliberately ignored as it did not explain additional information about the ecomorphological pattern. High scores on PC1 were associated with compression index, CI, whereas low scores were associated with relative head height, RHH and relative eyes position, REP. Similarly, high scores on PC2 were associated with relative height of head, RHH and relative length of head, RLH and low scores were associated with mouth aspect ratio, MAR and compression index, CI (Table 5). Subsequently, partitioning clustering was done, following $k$-means clustering considering $X$-axis as PC1 (position and locomotion related capability) and $Y$-axis as PC2 (foraging capability) (Fig. 4). Thus, partitioning differentiated the species into three clusters. It is clear from the result that clusters 1 and 2 had high association on PC2 but in opposite directions (Table 6). Where mean foraging capability of species belonging to cluster 1 is stronger than overall mean foraging capability prevailing on the same ecosystem ( $v$-test statistics $=2.411, p<0.05)$, the same is weaker for the species belonging to cluster $2(v$ test statistics $=-2.515, p<0.05$ ). Cluster 3 was associated with PC1 (locomotion related capacity) suggested a mean manoeuvring capability for the species belonging to that 
cluster which is stronger than overall average manoeuvring capability ( $v$-test statistics $=$ 2.425, $p<0.05)$.

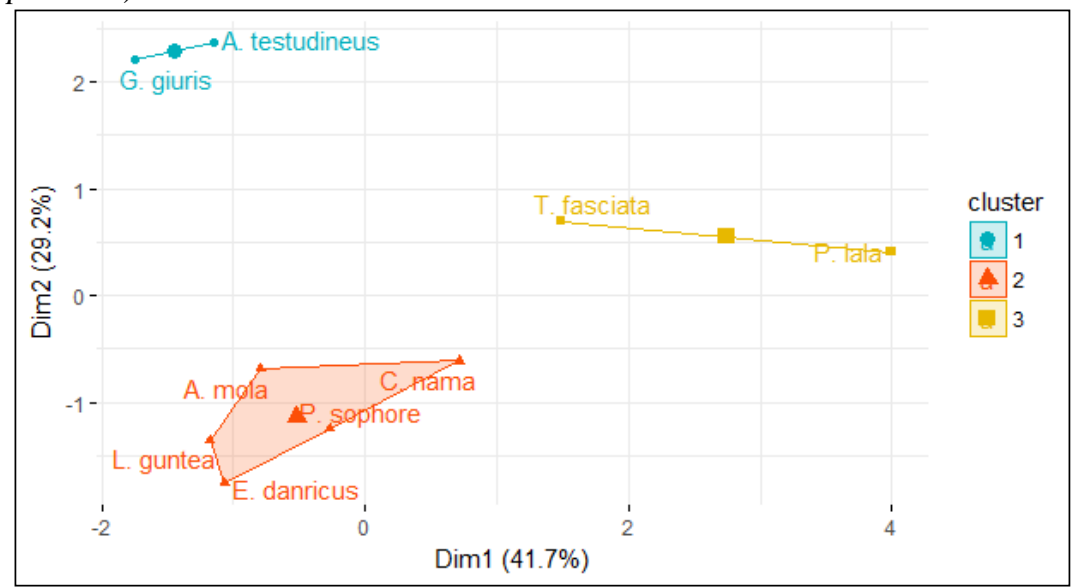

Fig. 4. $k$-Means partitioning clustering plot.

Table 5. Loading values of PCA on seven ecomorphological indices from nine fish species.

\begin{tabular}{lll}
\hline Variables & PC1 & PC2 \\
\hline Relative length of head (RLH) & 0.216 & 0.5828 \\
Relative height of head (RHH) & -0.2442 & 0.5142 \\
Relative area of eye (RAE) & 0.363 & 0.4025 \\
Mouth aspect ratio (MAR) & 0.452 & -0.2963 \\
Relative height (RH) & 0.472 & 0.1873 \\
Compression index (CI) & 0.5564 & -0.1046 \\
Relative eyes position (REP) & -0.1385 & 0.3165 \\
\hline
\end{tabular}

Table 6. Principal components for best describing each cluster.

\begin{tabular}{|c|c|c|c|c|}
\hline & Species & $\begin{array}{l}\text { Variable } \\
\text { significant }\end{array}$ & Most associated with & $v$. test \\
\hline Cluster 1 & $\begin{array}{l}\text { A.testudineus } \\
\text { G. giuris }\end{array}$ & RHH & $\begin{array}{l}\text { PC2 } \\
\text { (Foraging ) }\end{array}$ & $2.411 *$ \\
\hline Cluster 2 & $\begin{array}{l}\text { A. mola } \\
\text { C. nama } \\
\text { P. sophore } \\
\text { L. guntea } \\
\text { E. danrica }\end{array}$ & $\begin{array}{l}\text { RAE } \\
\text { RLH }\end{array}$ & $\begin{array}{l}\text { PC2 } \\
\text { (Foraging) }\end{array}$ & $-2.505^{*}$ \\
\hline Cluster 3 & $\begin{array}{l}\text { T. fasciata } \\
\text { P. lala }\end{array}$ & $\begin{array}{l}\text { RH } \\
\text { CI } \\
\text { MAR }\end{array}$ & $\begin{array}{l}\text { PC1 } \\
\text { (Locomotion and } \\
\text { position) }\end{array}$ & $2.425 *$ \\
\hline
\end{tabular}

$* p<0.05$

A major characteristic feature for the species belonging to Cluster 1 may be assigned to carnivory nature of feeding (G. giuris and A. testudineus). The significant variable for describing the cluster 1 found to be the RHH. The head heights of representative species 
are relatively larger than other selected species. On the other hand, cluster 2 is comprised of the species that have length of head and eye area relatively smaller than other representative species (Cypriniformes fish- P. sophore, L. guntea, E. danrica, A. mola and Perciformes fish- C. nama). Cluster 3 is characterized by comparatively larger mouth aspect ratio, highly compressed body and higher capacity to make vertical turns and represented by Perciformes fish P. lala and Anabantiformes fish T. fasciata.

\subsection{Convergent and divergent patterns of fish assembly}

In ecomorphological studies of fishes, two distinct approaches were followed. The first approach focuses on morphological traits that explain the feeding behaviour of the studied species. This approach assumes that traits of feeding behaviour (e.g. mouth gap, jaw length, length of the alimentary tract, etc.) are related to the diet of the fish [46]. The second approach focuses on habitat use and locomotion or position of the fish species based on some distinct features like body length, configuration of the fin, eye position etc. This approach encompasses specific ecological aspect like habitat use describing any divergence or convergence of the species in a particular habitat $[22,47,48]$. In the present study, both the approaches have been combined for explaining the strategy that SFSs adopt to explore spatial as well as trophic resources in lentic habitat.

Most of the ecomorphological studies ignore 'taxonomic signal' that may greatly mislead the outcome. The taxonomic signal hypothesis suggests that closely related taxa have more similar trophic niches than distantly related taxa [49]. That is why the present study maintained a comprehensive analysis with and without taxonomic relatedness of the studied SFSs to get realised assembly pattern as an adaptive strategy of small fishes. Results from the present study revealed that taxonomic relatedness strongly influenced the assemblage pattern related to foraging. Such finding is incongruent with the findings of several other authors [50-52].

In contrast to the strong association between foraging and taxonomic relatedness, a weak association between habitat use and taxonomic relatedness was found. Such an outcome was not desirable for SFSs since the orders of Cypriniformes and Perciformes are not phylogenetically distantly situated [53]. Similarly, Families like Osphronemid and Anabantidae are also phylogenetically close [54]. The weak assemblage pattern related to habitat use may happen since habitat use corresponds to a range of functional traits, not only taxonomic signals. It indirectly hints for two contra stated pattern of fish assembly, viz., convergent and divergent assembly. Even though taxonomic signal hypothesis supports strong convergent assembly for feeding behaviour, the hypothesis of limiting similarity supports intense competition among taxonomically related species for the same pool of resources favouring trophic-niche divergence of species [55,56]. Such divergence is more predictable when taxonomically related species share high niche overlap. Therefore, the weak influence of taxonomic relatedness on the assembly pattern of SFSs for habitat use in the present case might have other explanation. Lechêne et al. [57] opined that trait convergence data must be interpreted with caution. In the present case, 
the question whether assembly pattern of SFSs for foraging is independent of all underlying limiting factors including taxonomic relatedness, or the assembly pattern for habitat use is guided by other gradients in the habitat requires careful analysis of the results.

For that, the taxonomic relatedness was removed, and interestingly, that outcome showed a strong association of morphological traits and trophic structure indicating a pattern of new fish assemblage independent of taxonomic influence. It could be assumed that in case of SFSs, which are, in general, closely taxonomically related, the taxonomic signal hypothesis might be strongly operative. Since foraging is a function strongly related to feeding habits, the taxonomic influence is desirable in the formation of assembly pattern. The concept relies on the facts that closely related species often exhibit the same feeding behaviour [58,59], and feeding can be rarely predictable above the generic level [60]. However, the strong relationship of morphological traits and trophic structure affirm that SFSs may independently assemble beyond taxonomic influence. Such assemblage reveals two distinguished inclinations, the first associated with locomotion and position while the second is with foraging. For these two tendencies, the species were clustered into three predominant clusters (designated as cluster 1, cluster 2 and cluster 3 ).

The cluster 1 represented by piscivorous fishes with larger gape, longer lower jaw, and relatively longer head height can capture a potentially larger prey [19,61-64]. The small needle-like villiform teeth help in capturing and holding prey in elongated jaws and manipulate them to a headfirst position for swallowing [65]. It has been reported [66] that adult $G$. giuris of greater than $5 \mathrm{~cm}$ length switches from small planktonic diet to more energy-rich carnivorous diet like fish fry, insect, shrimps. This fish prefers to lie on the bottom layer, has dorsally oriented mouth [67-69] and thus can attack preys of the upper water layer [65]. Similar to G. giuris, the species A. testudineus has lower jaw slightly longer than the upper jaw. The protrusion of the upper jaw is a function of mandible depression [70,71] which moves the mouth suddenly closure to the prey [72,73]. By this manner, fish can suck food particles from a distance up to 25 to $50 \%$ of its head length $[72,74]$ and may better handle larger prey. Thus, a distinctive piscivorous assembly is prominent with defined morphological features.

The cluster 2 is formed of mixed trophic groups and consumes smaller sized prey and use less vision during predation. The omnivores in this group have additional gustatory features or mechanoreceptors like taste buds on gill rakers, lips and palatal organs (in $P$. sophore) [40] or barbels (in L. guntea and E. danrica) [19]. These features help the fish to locate prey in darkness of bottom water or highly turbid water and approve that low vision with small eye area does not act as limiting factor for browsing or feeding [65,69,75,76]. Each representative of the cluster has a relatively smaller length of head and thus captures smaller-sized prey. Like A. mola, which is a surface dweller and size-selective phytoplankton feeder, feeds upon Chlorophyceae, Cyanophyceae, Bacillariophyceae and Euglenophyceae ranging from 2 to $12 \mu \mathrm{m}$ in size [29]. This group form an assemblage of fish species feeding on smaller sized prey (e.g., plankton and macroplankton) with an ability to prey in a low light environment. 
Cluster 3 is comprised of fish that have a short and deep body and are column feeders. As both the fish species are column feeders [33], they have to swim faster in increased midwater velocity [77]. A short and deep body can provide greater manoeuvrability in the water. These column feeders when rotating their body along transverse axis or vertical axis, the power required for angular velocity for overcoming the drag, is least if the body is short and deep [72]. It has been found that the fish Astronotus crassipinnis and Serrasalmus marginatus having short and compressed body present greater manoeuvrability [78]. Another characteristic of this cluster is a larger aspect ratio of mouth which is adapted for the preference over zooplankton and terrestrial insects [69].

\section{Conclusion}

Based on the outcomes of the present study, it is concluded that ecomorphological assemblage of small freshwater fish structure is primarily regulated by taxonomic signal hypothesis. The assemblage pattern is also determined by the trophic structure of the fish independently of the taxonomic influence. This otherwise, indicates a tendency of small fish to converge interspecifically forming morphological assemblage pattern facilitating resource exploration based on specific morphological traits. This outcome is new, especially for SFSs, and highlights the elasticity of the adaptation of SFSs through 'morphological tools' in smaller lentic aquatic bodies. Such information could further provide a basis for conservation of SFSs through species-specific ecosystem management approach.

\section{Acknowledgments}

Authors acknowledge UGC, New Delhi for financial support through UGC-BSR fellowship. The CAS-II and DST-FIST program of the department is also acknowledged for material support to the work. The support extended by DST-PURSE program of the 'Siksha-Bhavana' is also acknowledged. Help rendered by A. Banerjee in image processing is thankfully acknowledged.

\section{References}

1. R. McN. Alexander, Neth. J. Zool. 38, 3 (1988). http://doi.org/10.1163/156854288X00012

2. C. G. Montana and K. O. Winemiller, Biol. J. Linn. Soc. 109, 146 (2013). http://doi.org/10.1111/bij.12021

3. T. Bridge, R. K. Kosaki, T. C. L. Bridge, O. J. Luiz, R. R. Coleman, C. N. Kane, and R. K. Kosaki, Proc. Royal Soc. B 283 (2016). http://doi.org/10.1098/rspb.2015.2332

4. P. C. Wainwright, and D. R. Bellwood, Ecomorphology of Feeding in Coral Reef Fishes, in P. F. Sale Edition, Coral Reef Fishes: Dynamics and Diversity in A Complex Ecosystem (Academic Press, San Diego, 2002).

5. D. Faye, F. Le Loc'h, O. T. Thiaw, and L. T. Morais, Afr. J. Agric. Res. 7, 443 (2012).

6. P. Angermeier, and M. Winston, Ecol. Appl. 9, 335 (1999).

7. K. O. Winemiller, Can. J. Fish. Aquat. Sci. 62, 872 (2005). https://doi.org/10.1139/f05-040 
8. A. Oikonomou, F. Leprieur, and I. D. Leonardos, Environ. Biol. Fishes 101, 1121 (2018). https://doi.org/10.1007/s10641-018-0759-6

9. A. A. Pease, A. A. González-Díaz, R. Rodiles-Hernandez, and K. O. Winemiller, Freshw. Biol. 57, 1060 (2012).

10. B. E. Soares, T. O. B. Ruffeil, and L. F. deA. Montag, Neotrop. Ichthyol. 11, 845 (2013). http://doi.org/10.1590/S1679-62252013000400013

11. E. D. Dibble and F. M. Pelicice, Ecol. Freshw. Fish 19, 381 (2010).

12. U. K. Sarkar and W. S. Lakra, Aquac. Asia Magazine 15, 34 (2010).

13. P. L. Angermeier, Conserv. Biol. 9, 143 (1995). http://doi.org/10.1046/j.15231739.1995.09010143.x

14. J. D. Olden, Z. S. Hogan, and M. J. Vander Zanden, Glob. Ecol. Biogeogr. 16, 694 (2007). http://doi.org/10.1111/j.1466-8238.2007.00337.x

15. A. H. Arthington, N. K. Dulvy, W. Gladstone, and I. J. Winfield, Aquat. Conserv.: Mar. Freshw. Ecosyst. 26, 838 (2016). http://doi.org/10.1002/aqc.2712

16. I. Hanski, Anim. Conserv. 16, 12 (2013). http://doi.org/10.1111/acv.12024

17. P. S. D. MacRae and D. A. Jackson, Can. J. Fish. Aquat. Sci. 58, 342 (2001). http://doi.org/10.1139/cjfas-58-2-342

18. W. J. Matthews and E. Marsh-Matthews, Freshw. Biol. 48, 1232 (2003). http://doi.org/10.1046/j.1365-2427.2003.01087.x

19. P. K. Talwar and A. G. Jhingran, Inland Fishes of India and Adjacent Countries (Oxford, New Delhi, 1991)

20. IUCN (International Union for the Conservation of Nature) The IUCN Red List of Threatened Species (2018). http://www.iucnredlist.org (Accessed 12 Nov., 2018).

21. M. Pouilly, F. Lino, J. G. Bretenoux, and C. Rosales, J. Fish Biol. 62,1137 (2003). http://doi.org/10.1046/j.1095-8649.2003.00108.x

22. S. C. Willis, K. O. Winemiller, and H. Lopez-Fernandez, Oecologia 142, 284 (2005). http://doi.org/10.1007/s00442-004-1723-z

23. K. O. Winemiller, Ecol. Monogr. 61, 343 (1991). http://doi.org/10.2307/2937046

24. A. C. Beaumord and M. Petrere Jr, Acta Biol. Venez. 15, 21 (1994).

25. D. J. Watson, and E. K. Balon, J. Fish Biol. 25, 371 (1984). http://doi.org/10.1111/j.10958649.1984.tb04885.x

26. A. J. Jr. Gatz, Ecology 60, 711 (1979). http://doi.org/10.2307/1936608

27. S. Das, S. Nandi, S. Majumder, and S. K. Saikia, J. Fisheries Sci. Com. 7, 225 (2013).

28. D. K. Mondal and A. Kaviraj, Int. J. Aquat. Biol. 1, 125 (2013).

29. S. Nandi and S. K. Saikia, J. Fish Biol. 87, 215 (2015). http://doi.org/10.1111/jfb.12706

30. C. S. Rao and S. Kallepalli S, Bio. Disc. 8, 184 (2017).

31. S. K. Ghosh, B. Ghosh, and P. Chakrabarti, Acta Ichthyol. Piscat. 41, 1 (2011). http://doi.org/10.3750/AIP2011.41.1.01

32. A. R. Grubh and K. O. Winemiller, Copeia 2004903 (2004). http://doi.org/10.1643/CE-02$\underline{095 R 1}$

33. G. Chandra, I. Bhattacharjee, S. N. Chatterjee, and A. Ghosh, Ind. J. Med. Res. 127, 13 (2008).

34. S. Gupta, Int. J. Fish. Aquac. 5, 147 (2015).

35. K.H. Alikunhi, G. L. Rao, and P. K. Jacob, J. Madras Univ. 2, 238 (1951).

36. C. M. Talde, A. C. Mamaril SR, and M. L. D. Palomares, Sri Lanka J. Aquat. Sci. 9, 45 (2004). http://doi.org/10.4038/sljas.v9i1.7465

37. M. N. Islam, J. Biol. Sci. 4, 780 (2004). http://doi.org/10.3923/jbs.2004.780.793

38. S. Hossain, A. Roy, and M. L. Rahman, Int. J. Fish. Aquat. Stud. 4, 84 (2016).

39. I. Bhattacharjee and G. Chandra, Int. J. Fish. Aquat. Stud. 4, 586 (2016).

40. P. Tripathi, A. K. Mittal, Tissue Cell 42, 223 (2010). http://doi.org/10.1016/j.tice.2010.04.005

41. T. Abbasi and S. A. Abbasi, Indices of Biological Integrity or the Multi-metric Indices, in Water Quality Indices, $1^{\text {st }}$ Edition (Elsevier, Amsterdam, 2012) pp. 249-324.

42. P. Legendre and L. F. J. Legendre, Numerical Ecology (Elsevier, Amsterdam, 1998). 
43. N. J. Gotelli and A. M. Ellison, A Primer of Ecological Statistics (Sinauer Associates, Massachusetts, 2004).

44. Ø. Hammer, D. A. T. Harper, and P. D. Ryan, PAST: Paleontological Statistics Software Package for Education and Data Analysis, Palaeontol. Electron. 5 (2001). http://palaeoelectronica.org/2001_1/past/issue1_01.htm

45. S. Lê, J. Josse, and F. Husson, FactoMineR: An R Package for Multivariate Analysis, J. Stat. Softw. 25, (2008). https://www.jstatsoft.org/article/view/v025i01

46. P. C. Wainwright and B. A. Richard, Environ. Biol. Fishes 44, 97 (1995).

47. K. O. Winemiller, Nat. Geographic Res. Explorat. 8, 308 (1992).

48. L. F. Stegmann, R. P. Leitão, J. Zuanon, and W. E. Magnusson, PLoS One 14, ID e0223880 (2019). https://doi.org/10.1371/journal.pone.0223880

49. A. M. Potapov, S. Scheu, and A.V. Tiunov, Funct. Ecol. 33, 1172 (2019). http://doi.org/10.1111/1365-2435.13309

50. A. M. Davis, P. J. Unmack, B. J. Pusey, J. B. Johnson, and R. G. Pearson, J. Evol. Biol. 25, 1163 (2012). http://doi.org/10.1111/j.1420-9101.2012.02504.x

51. K. W. Cummins, J. Limnol. 75, 235 (2016). https://doi.org/10.4081/jlimnol.2016.1373.

52. J. P. F. Pomeranz, R. M. Thompson, T. Poisot, and J. S. Harding, Methods Ecol. Evol. 10, 356 (2019). https://doi.org/10.1111/2041-210X.13125

53. M. Raja and P. Perumal, J. Phylogenet. Evolut. Biol. 5, ID 1000184 (2017). https://doi.org/10.4172/2329-9002.1000184

54. R. Betancur-R., R. E. Broughton, E. O. Wiley, K. Carpenter, J. A. López, C. Li, N. I. Holcroft, D. Arcila, M. Sanciangco, J. C. Cureton II, F. Zhang, T. Buser, M. A. Campbell, J. A

Ballesteros, A. Roa-Varon, S. Willis, W. C. Borden, T. Rowley, P. C. Reneau, D. J. Hough, G. Lu, T. Grande, G. Arratia, and G. Ortí, PLOS Curr. 5 (2013). https://doi.org/10.1371/currents.tol.53ba26640df0ccaee75bb165c8c26288

55. R. H. MacArthur and R. Levins, Am. Nat. 101, 377 (1967).

56. P. A. Abrams, Ann. Rev. Ecol. Syst. 14, 359 (1983). https://doi.org/10.1146/annurev.es.14.110183.002043

57. A. Lechêne, J. Lobry, P. Boët, and P. Laffaille, PLoS One 13, ID e0209025 (2018). https://doi.org/10.1371/journal.pone.0209025

58. D. Simberloff and T. Dayan, Annu. Rev. Ecol. Evol. Syst. 22, 115 (1991). https://doi.org/10.1146/annurev.es.22.110191.000555

59. A. Potapov, E. E. Semenina, A.Y. Korotkevich, N. A. Kuznetsova, and A.V. Tiunov, Soil Biol. Biochem. 101, 20 (2016).

60. D. E. Walter and E. K. Ikonen, J. Nematol. 21, 315 (1989).

61. S. F. Norton and E. L. Brainerd, J. Exp. Biol. 176, 11 (1993).

62. S. H. Huskey and R. G. Turingan, Environ. Biol. Fishes 61, 185 (2001). https://doi.org/10.1023/A:1011095526939

63. C. Magnhagen and E. Heibo, Funct. Ecol. 15, 754 (2001). https://doi.org/10.1046/j.0269$\underline{8463.2001 .00576 . \mathrm{x}}$

64. T. M. Detmer, L. M. Einfalt, J. J Parkos, and D. H. Wahl, Environ. Biol. Fishes 101, 449 (2018). https://doi.org/10.1007/s10641-017-0710-2

65. G. H. Helfman, B. B. Collette, D. E. Facey, and B. W. Bowen, Functional Morphology of Locomotion and Feeding, in The Diversity of Fishes: Biology, Evolution and Ecology, $2^{\text {nd }}$ Edition (Wiley-Blackwell, New Jersey, 2009) pp. 111-128.

66. L. M. Rao and P. S. Rao, Indian J. Fish. 49, 35 (2002).

67. J. S. Pet and G. J. Weliange, J. Fish Biol. 43, 193 (1993) 193-208. https://doi.org/10.1111/j.1095-8649.1993.tb01187.x

68. G. J. Piet and W. A. H. P. Guruge, Environ. Biol. Fishes 50, 293 (1997).

69. G. J. Piet, Environ. Biol. Fishes 51, 67 (1998). https://doi.org/10.1023/A:1007338532482

70. B. R. Singh, Zool. Anz. 179, 409 (1968).

71. H. M. Dutta, Eur. J. Morphol. 17, 119 (1979). 
72. R. McN. Alexander, J. Zool. 151, 43 (1967). https://doi.org/10.1111/j.14697998.1967.tb02865.x

73. P. J. Motta, Copeia 1984, 1 (1984). https://doi.org/10.2307/1445030

74. J. W. M. Osse, Animal Biol. 19, 289 (1969). https://doi.org/10.1163/002829669X00134

75. W. S. Weliange and U. S. Amarasinghe, Asian Fish. Soc. 16, 203 (2003).

76. S. Mittal, P. Tripathi, and A. K. Mittal, Belg. J. Zool. 134, 9 (2004).

77. P. C. Wainwright, D. R. Bellwood, and M. W. Westneat, Environ. Biol. Fishes 65, 47 (2002). https://doi.org/10.1023/A:1019671131001

78. E. F. Oliveira, E. Goulart, L. Breda, C. V. Minte-vera, L. Ricardo, D. S. Paiva, and M. R. Vismara, Neotrop. Ichthyol. 8, 569 (2010). 